\title{
32. ORGANIC GEOCHEMICAL COMPARISON OF CRETACEOUS GREEN AND BLACK CLAYSTONES FROM HOLE 530A IN THE ANGOLA BASIN ${ }^{1}$
}

\author{
Philip A. Meyers, Oceanography Program, Department of Atmospheric and Oceanic Science, \\ Thomas W. Trull, ${ }^{2}$ Senior Honors Project, Department of Chemistry \\ and \\ Orest E. Kawka, ${ }^{3}$ Oceanography Program, Department of Atmospheric and Oceanic Science, The University of \\ Michigan, Ann Arbor, Michigan
}

\begin{abstract}
Three pairs of Upper Cretaceous black shales and adjacent green claystones from Hole 530A were analyzed to compare types and amounts of organic matter and lipids and to seek information about their environments of deposition. The organic-carbon-rich black shales have $\mathrm{C} / \mathrm{N}$ ratios nearly seven times those of the organic-carbon-lean green claystones. The lipid content of organic matter in the black shales is about ten times less than in adjacent green layers. Organic matter in both types of rocks is thermally immature, and distributions of alkanoic acids, alkanols, sterols, and alkanes contain large amounts of terrigenous components. Pristane/phytane ratios of less than one suggest that younger Turonian sediments were laid down under anoxic conditions, but ratios greater than one suggest that older Turonian Cenomanian deposits accumulated in a more oxic environment. Closely bedded green and black layers have very similar types of lipid distributions and differ primarily in concentrations, although black shales contain somewhat larger amounts of terrigenous lipid components. Geochemical and stratigraphic evidence suggests much of the organic matter in these samples originated on the African continental margin and was transported to the Angola Basin by turbidity flow. Rapid reburial of organic-carbon-rich sediments led to formation of the black shales.
\end{abstract}

\section{INTRODUCTION}

Black shales containing high amounts of organic matter were deposited in deep waters of the South Atlantic during the Cretaceous period. Occurrences of black shale formation are found in the Barremian-Aptian at Deep Sea Drilling Project (DSDP) Site 361 in the Cape Basin and at Sites 327 and 330 on the Falkland Plateau, in the Albian at Site 363 on the northern flank of Walvis Ridge, in the Turonian-Santonian at Site 356 on the Sao Paulo Plateau, and in the Aptian-Albian and Turonian-Santonian at Site 364 in the Angola Basin (Bolli, Ryan et al., 1978). Concentrations of organic carbon reach as high as $\mathbf{2 4 \%}$ dry weight of Aptian sediment at Site 364 (Foresman, 1978). The conditions which led to the formation of these organic-carbon-rich layers are not understood, although some combination of low availability of oxygen and abundant supply of organic matter seems likely.

Primary among the scientific goals of DSDP Leg 75 was to investigate the Cretaceous paleoceanographic conditions in which black shales were formed. Hay et al. (1982) summarize information obtained from Site 530 in the Angola Basin where black shale layers were found in the Albian to early Coniacian. They conclude that organic-carbon-rich sediments accumulated in an oxygen minimum zone of varying intensity on the African continental slope and were redeposited in deep waters by

\footnotetext{
${ }^{1}$ Hay, W. W., Sibuet, J.-C., et al., Init. Repts. DSDP, 75: Washington (U.S. Govt. Printing Office).

2 Present address: Woods Hole Oceanographic Institution, Woods Hole, Massachusetts.

${ }^{3}$ Present address: School of Oceanography, Oregon State University, Corvallis, Oregon.
}

turbidity flows and slumping. Preservation of organic matter in the deep-water environment was enhanced by rapid burial in the bottom.

Organic geochemistry can provide information which will help answer some of the questions about black shales. Evidence of biological sources and of depositional environments is often preserved in the elemental and molecular composition of organic matter in rocks and sediments. In the case of the Aptian to Coniacian rocks at Site 530, relatively thin layers of black shales are interbedded with thicker layers of organic-carbonlean green and red claystones (Site 530 summary, this volume). The differences in bulk organic contents and in color indicate changes in depositional conditions and possibly variations in supply of organic matter. Analyses of total organic carbon, $\mathrm{C} / \mathrm{N}$ atomic ratios in organic matter, and lipid composition of samples from closely bedded green and black layers were done to compare the organic matter character of these different rocks.

\section{METHODS}

Six samples were collected on board D/V Glomar Challenger from freshly opened core sections from Hole 530A for the purpose of this comparative study. Two younger Turonian samples, one green claystone and one black shale, were selected from Section 530A-95-5. These samples were halved longitudinally and shared between this study and the kerogen study described by Deroo et al. (this volume). Four older Turonian samples from Section 530A-97-1 consist of a green claystone overlying a black shale layer, the top of the black shale layer, the bottom of the black shale layer, and the underlying green claystone. The samples were immediately frozen in heat-sealed Kapak bags and kept frozen until analyzed.

Samples were first freeze-dried, and then their total carbon content was measured with a Hewlett-Packard 185B CHN analyzer. Residual carbon was measured after $\mathrm{HCl}$ dissolution of carbonates and was considered to represent the total organic carbon content. Percent cal- 
cium carbonate was calculated from the difference between initial and residual carbon contents. Atomic $\mathrm{C} / \mathrm{N}$ ratios of organic matter were determined from residual carbon $\mathrm{CHN}$ values. Percent organic carbon contents of the samples were calculated on a dry-weight basis for the original carbonate-containing sediment.

A two-stage procedure was used to extract lipids from the freezedried samples. Soxhlet extraction with toluene/methanol yielded the easily extracted materials. A second extraction with $0.5 \mathrm{~N} \mathrm{KOH}$ in methanol/toluene provided the hydrolyzable fraction of components. These are called the free and bound fractions, respectively, in this chapter and are comparable to the free and bound fractions of Brassell et al. (1980). Both fractions were treated with methanolic boron trifluoride to convert fatty acids to their methyl esters, and then lipid subfractions were separated by column chromatography on silica gel. The classes so obtained contained aliphatic hydrocarbons, fatty acid methyl esters, and hydroxy lipids, including sterols and alkanols. Hydroxy compounds were silylated with BSTFA prior to gas chromatography (GC).

Splitless injection gas-liquid chromatography was employed to determine the types and amounts of compounds comprising the lipid subfractions. A Hewlett-Packard 5830 FID gas chromatograph equippedwith a $20 \mathrm{~m}$ SE54 glass capillary column was used with hydrogen as carrier gas. Quantification was accomplished through the use of known amounts of internal standards added to each sample before column chromatography and includes corrections for GC response differences and laboratory contaminants. Individual compounds were tentatively identified by GC retention times in this preliminary survey of the lipid character of these rocks.

\section{RESULTS AND DISCUSSION}

\section{Organic Carbon and $\mathbf{C} / \mathbf{N}$ Values}

Black shale samples have much higher concentrations of organic carbon and much higher $\mathrm{C} / \mathrm{N}$ ratios than do the green shales (see Table 1). These differences in the amount of organic matter and in its elemental composition are consistent with those found in a large assortment of samples from layers of black shales and red and green claystones in Cretaceous rocks from Hole 530A (Site 530 summary; Meyers et al., this volume).

Concentrations of organic carbon of the green claystones average $0.53 \%$ and are only slightly higher than the averages of $0.2 \%$ found in modern, deep-ocean sediments (Degens and Mopper, 1976) and of 0.3\% compiled by McIver (1975) from analyses of older marine deposits from DSDP Legs 1 through 31 . The organic matter in these layers probably was buried in sediments deposited under oxygenated bottom waters, a situation which does not favor organic matter preservation (Hinga et al., 1979; Cobler and Dymond, 1980; Demaison and Moore, 1980). This material may have experienced further postdepositional destruction as documented by Waples and Sloan (1980) in samples from DSDP Leg 58. In contrast to the green claystones, the black shale samples contain concentrations of organic carbon which

Table 1. General descriptions of samples selected for organic geochemical comparison of green and black layers, Hole 530A.

\begin{tabular}{lclllrr}
\hline $\begin{array}{c}\text { Core-Section } \\
\text { (interval in cm) }\end{array}$ & $\begin{array}{c}\text { Sub-bottom } \\
\text { depth } \\
(\mathrm{m})\end{array}$ & \multicolumn{1}{c}{ Age } & Lithology & $\begin{array}{c}\mathrm{CaCO}_{3} \\
(\%)\end{array}$ & $\begin{array}{r}\mathrm{C}_{\text {org }} \\
(\%)\end{array}$ & C/N \\
\hline $95-5,0-21$ & 1014 & Younger Turon. & Green claystone & $<1$ & 0.20 & 4.5 \\
$95-5,38-50$ & 1014 & Younger Turon. & Black shale & $<1$ & 12.95 & 36.0 \\
$97-1,87-91$ & 1027 & Older Turon. & Green claystone & $<1$ & 0.58 & 6.8 \\
$97-1,91-95$ & 1027 & Older Turon. & Black shale & $<1$ & 4.89 & 38.1 \\
$97-1,99-105$ & 1027 & Older Turon. & Black shale & $<1$ & 10.01 & 40.3 \\
$97-1,105-110$ & 1027 & Older Turon. & Green claystone & $<1$ & 0.80 & 5.7 \\
\hline
\end{tabular}

are unusually high for most marine sediments. Such high values have been reported for only a few modern locations, generally under anoxic or poorly oxygenated bottom waters as summarized in Demaison and Moore (1980). An uncommon combination of abundant supply of organic matter and of exceptional preservation in sediments is required for these organic-carbon-rich deposits to accumulate.

The contrast in $\mathrm{C} / \mathrm{N}$ ratios between the green claystones and black shales may reflect different amounts of diagenesis of organic matter, different sources of organic matter, or some combination of these two possibilities. Atomic $\mathrm{C} / \mathrm{N}$ ratios of the green claystones average 5.7 (Table 1), a value similar to those found in DSDP Leg 58 sediments (Waples and Sloan, 1980). Such low ratios reflect greater diagenetic loss of organic carbon than of nitrogen, because surficial marine sediments commonly have $\mathrm{C} / \mathrm{N}$ ratios in the range of 9 to 18 (Stevenson and Cheng, 1972; Müller, 1977). In organiccarbon-lean samples like the green claystones, $\mathrm{C} / \mathrm{N}$ ratios can be affected by the presence of inorganic ammonium and by organic nitrogen compounds sorbed to clay minerals (Müller, 1977), and thus they may not be reliable indicators of sources of organic matter. In the case of the organic-carbon-rich black shales, however, the high concentrations of organic matter override the effects of these minor nitrogen contributions. The atomic $\mathrm{C} / \mathrm{N}$ ratios average 38.1 in the black shales and may indicate an important land-plant contribution to the sediment organic matter (cf. Müller, 1977). Carbon isotopic analyses of DSDP Leg 40 samples also suggest the possibility of terrigenous material in black shales deposited during Cretaceous times in the Angola Basin (Foresman, 1978; Simoneit, 1978a). However, Hinga et al. (1979) report elemental analyses of diatom debris from sediment traps in the North Atlantic Ocean which yield atomic C/N ratios of 28 to 54, and Dean et al. (1981) show a correlation between high organic-carbon content and greater depletion in ${ }^{13} \mathrm{C}$ in mid-Cretaceous marine limestones samples from the Hess Rise during DSDP Leg 62. Evidently, much remains to be learned about the effects of diagenesis upon elemental and isotopic compositions of organic matter, and $\mathrm{C} / \mathrm{N}$ ratios and carbon isotopic data must be interpreted with caution.

\section{Free and Bound Lipid Components-General}

Representative chromatograms of lipid fractions are presented in Figure 1. Identification and quantification of individual lipid components are based upon integrated peak areas from such chromatograms with corrections for mass discrimination over the fairly broad molecular weight range surveyed. Identifications must be considered tentative until verified by combined gas chromatography-mass spectrometry analyses now underway. Laboratory contamination of samples was minor, and corrections have been made for it in our data. No obvious evidence of shipboard contamination was observed (cf. Doran and Johnson, 1979).

Lipid contents of the green claystones and black shales analyzed in this chapter are summarized in Table 2. In general, free lipids are at higher concentrations 
Table 2. Summary of geolipid contents of samples of green claystones and black shales, Hole 530A.

\begin{tabular}{|c|c|c|c|c|c|c|c|c|c|c|c|c|}
\hline \multirow[b]{4}{*}{ Geolipid component } & \multicolumn{12}{|c|}{$\begin{array}{c}\text { Sample } \\
\text { (interval in } \mathrm{cm} \text { ) }\end{array}$} \\
\hline & \multicolumn{2}{|c|}{$95-5,0-21$} & \multicolumn{2}{|c|}{$95-5,38-50$} & \multicolumn{2}{|c|}{$97-1,87-91$} & \multicolumn{2}{|c|}{$97-1,91-95$} & \multicolumn{2}{|c|}{$97-1,99-105$} & \multicolumn{2}{|c|}{$97-1,105-110$} \\
\hline & Green & claystone & Black & shale & Green & claystone & Black & shale & Black & shale & Green & claystone \\
\hline & Free & Bound & Free & Bound & Free & Bound & Free & Bound & Free & Bound & Free & Bound \\
\hline \multicolumn{13}{|l|}{ Hydrocarbons } \\
\hline $\begin{array}{l}\text { Total, } \mu \mathrm{g} / \mathrm{g} \text { sediment } \\
\text { Total, } \mathrm{mg} / \mathrm{g} \mathrm{C}_{\text {org }} \\
n \text {-alkanes, } \mu \mathrm{g} / \mathrm{g} \text { sediment } \\
n \text {-alkanes, mg } / \mathrm{g} \mathrm{C} \mathrm{C}_{\text {org }} \\
\text { Pristane/phytane } \\
\text { Pristane } / n-\mathrm{C}_{17} \\
n-\mathrm{C}_{29} / n-\mathrm{C}_{17} \\
\text { CPI }(16-32)\end{array}$ & 0.86 & 1.8 & 0.83 & & $\begin{array}{l}6.9 \\
1.2 \\
1.8 \\
0.31 \\
1.6 \\
2.1 \\
6.5 \\
0.94\end{array}$ & $\begin{array}{l}0.84 \\
0.14 \\
0.28 \\
0.048 \\
0.75 \\
0.50 \\
7.8 \\
0.95\end{array}$ & $\begin{array}{l}45 \\
0.92 \\
8.4 \\
0.17 \\
1.7 \\
3.2 \\
4.0 \\
1.6\end{array}$ & & $\begin{array}{l}180 \\
1.8 \\
27 \\
0.27 \\
1.3 \\
2.5 \\
1.5 \\
1.8\end{array}$ & $\begin{array}{l}0.85 \\
0.008 \\
0.35 \\
0.003 \\
0.91 \\
0.67 \\
8.3 \\
1.1\end{array}$ & $\begin{array}{l}35 \\
4.4 \\
5.7 \\
0.71 \\
1.2 \\
2.4 \\
0.56 \\
0.66\end{array}$ & $\begin{array}{l}0.88 \\
0.11 \\
0.32 \\
0.40 \\
0.90 \\
0.77 \\
0.69 \\
0.73\end{array}$ \\
\hline \multicolumn{13}{|l|}{ Fatty acids } \\
\hline $\begin{array}{l}\text { Total, } \mu \mathrm{g} / \mathrm{g} \text { sediment } \\
\text { Total, } \mathrm{mg} / \mathrm{g} \mathrm{C} \text { org } \\
n \text {-alkanoics, } \mu \mathrm{g} / \mathrm{g} \text { sediment } \\
n \text {-alkanoics, } \mathrm{mg} / \mathrm{g} \mathrm{C} \text { org } \\
n \text {-C } 26 / n \text {-C } 16 \\
\text { CPI }(16-32)\end{array}$ & $\begin{array}{l}3.4 \\
1.7 \\
2.1 \\
1.0 \\
0.27 \\
4.2\end{array}$ & $\begin{array}{l}2.8 \\
1.4 \\
1.7 \\
1.3 \\
0.12 \\
7.1\end{array}$ & $\begin{array}{l}6.7 \\
0.052 \\
4.8 \\
0.037 \\
0.63 \\
2.1\end{array}$ & $\begin{array}{l}3.8 \\
0.029 \\
2.7 \\
0.021 \\
0.33 \\
2.0\end{array}$ & $\begin{array}{l}2.3 \\
0.40 \\
1.5 \\
0.26 \\
0.37 \\
4.6\end{array}$ & $\begin{array}{l}1.4 \\
0.24 \\
0.69 \\
0.12 \\
0.083 \\
6.2\end{array}$ & $\begin{array}{l}6.5 \\
0.13 \\
4.0 \\
0.082 \\
1.08 \\
2.6\end{array}$ & & $\begin{array}{l}11.0 \\
0.11 \\
5.1 \\
0.051 \\
0.74 \\
2.2\end{array}$ & $\begin{array}{l}2.9 \\
0.029 \\
2.1 \\
0.021 \\
0.24 \\
2.4\end{array}$ & $\begin{array}{l}3.5 \\
0.44 \\
2.3 \\
0.29 \\
0.410 \\
3.7\end{array}$ & $\begin{array}{l}1.7 \\
0.21 \\
1.0 \\
0.13 \\
0.074 \\
4.5\end{array}$ \\
\hline \multicolumn{13}{|l|}{ Alkanols and sterols } \\
\hline $\begin{array}{l}\text { Total, } \mu \mathrm{g} / \mathrm{g} \text { sediment } \\
\text { Total, } \mathrm{mg} / \mathrm{g} \mathrm{C}_{\text {org }} \\
n \text {-alkanols, } \mu \mathrm{g} / \mathrm{g} \text { sediment } \\
n \text {-alkanols, } \mathrm{mg} / \mathrm{g} \mathrm{C} \mathrm{C}_{\text {org }} \\
n \text {-C } 28 / n-\mathrm{C}_{16} \\
\mathrm{CPI}(16-32) \\
\text { Sterols, } \mu \mathrm{g} / \mathrm{g} \text { sediment } \\
\text { Sterols, } \mathrm{mg} / \mathrm{g} \mathrm{C}_{\text {org }}\end{array}$ & $\begin{array}{l}0.40 \\
0.20 \\
0.066 \\
0.033 \\
0.19 \\
31 \\
0.026 \\
0.013\end{array}$ & $\begin{array}{l}0.76 \\
0.38 \\
0.10 \\
0.051 \\
1.3 \\
7.3 \\
0.069 \\
0.035\end{array}$ & $\begin{array}{l}5.1 \\
0.039\end{array}$ & $\begin{array}{l}2.0 \\
0.015 \\
0.12 \\
0.001 \\
1.3 \\
3.1 \\
0.20 \\
0.001\end{array}$ & $\begin{array}{l}1.6 \\
0.28 \\
0.12 \\
0.021 \\
1.3 \\
\quad \text { a } \\
0.16 \\
0.028\end{array}$ & $\begin{array}{l}1.5 \\
0.26 \\
0.13 \\
0.022 \\
4.0 \\
17 \\
0.043 \\
0.007\end{array}$ & $\begin{array}{l}4.6 \\
0.094 \\
0.20 \\
0.004 \\
1.7 \\
16 \\
0.61 \\
0.013\end{array}$ & $\begin{array}{l}1.7 \\
0.035 \\
0.22 \\
0.004 \\
3.1 \\
9.4 \\
0.072 \\
0.001\end{array}$ & $\begin{array}{l}8.6 \\
0.086 \\
0.59 \\
0.006 \\
7.7 \\
2.7 \\
1.4 \\
0.014\end{array}$ & $\begin{array}{l}2.9 \\
0.029 \\
0.23 \\
0.002 \\
2.0 \\
4.3 \\
0.21 \\
0.002\end{array}$ & $\begin{array}{l}3.0 \\
0.38 \\
0.46 \\
0.058 \\
5.9 \\
16 \\
0.32 \\
0.040\end{array}$ & $\begin{array}{l}1.0 \\
0.13 \\
0.063 \\
0.008 \\
0.66 \\
6.2 \\
0.017 \\
0.002\end{array}$ \\
\hline
\end{tabular}

Note: Blank space $=$ not determined.

a No odd-chain $n$-alkanols were detected.

than are bound lipids. This is especially true for the hydrocarbon fraction of total, or free plus bound, lipids. Free-to-bound ratios of concentrations range between 0.5 to 3.8 for fatty acids and alcohols and between 8 and over 200 for hydrocarbons. No consistent difference in this ratio exists between green and black layers. Concentrations of each lipid fraction per weight of dry rock are generally greater in black shales than in interbedded green claystones. However, the converse is found when concentrations are expressed in milligrams lipid per gram organic carbon, showing that the organic-carbon-rich black shales are lean in lipid components relative to other forms of organic matter. Degradation of nonlipid materials is the probable cause for green claystones to have higher proportions of lipid components. Among the lipid components, hydrocarbons have the greatest concentration, fatty acids are intermediate, and alcohols have the smallest concentration. Within the alcohol fractions, sterols and $n$-alkanols generally have roughly similar total concentrations.

\section{Aliphatic Hydrocarbons}

Ratios of biomarker hydrocarbons extracted from sediments and sedimentary rocks are commonly used to provide information about sources of organic matter, paleoenvironmental conditions of sedimentation, and diagenesis of organic matter. Pristane-to-phytane ratios less than one suggest anoxic depositional environments whereas ratios greater than one indicate oxic conditions (Didyk et al., 1978). The values in Table 2 from Section 530A-95-5 are about 0.85 for free hydrocarbons and 1.8 for bound hydrocarbons, and those from Section 530A97-1 are between 1.2 and 1.7 in the free hydrocarbon extracts and 0.75 to 0.91 in the bound extracts. Adjacent green and black samples have essentially the same pristane/phytane ratios. Because free hydrocarbons have higher concentrations than do the bound fractions, their marker compounds are probably more representative of the total extractable organic matter in these samples.

The low pristane/phytane ratios in the free hydrocarbon fractions of Samples 530A-95-5, 0-21 cm, and 530A$95-5,38-50 \mathrm{~cm}$ suggest that the organic matter in both these Turonian samples was buried under anoxic conditions. However, the green layer (Sample 530A-95-5, 0$21 \mathrm{~cm}$ ) was bioturbated, and so lack of oxygen must have been confined to the sediments. Other investigators have reported low pristane/phytane ratios in Cretaceous rocks from the Atlantic. For example, ratios of 0.6 and 0.3 have been measured in an Aptian black mudstone from DSDP Site 364 in the Angola Basin (Simoneit, 1978a) and for a Cenomanian black shale from DSDP Site 367 (Didyk et al., 1978), respectively, and indicate anoxic conditions accompanying deposition of these other organic-carbon-rich samples.

In contrast to Section 530A-95-5, the free hydrocarbon pristane/phytane ratios suggest at least mildly oxy- 


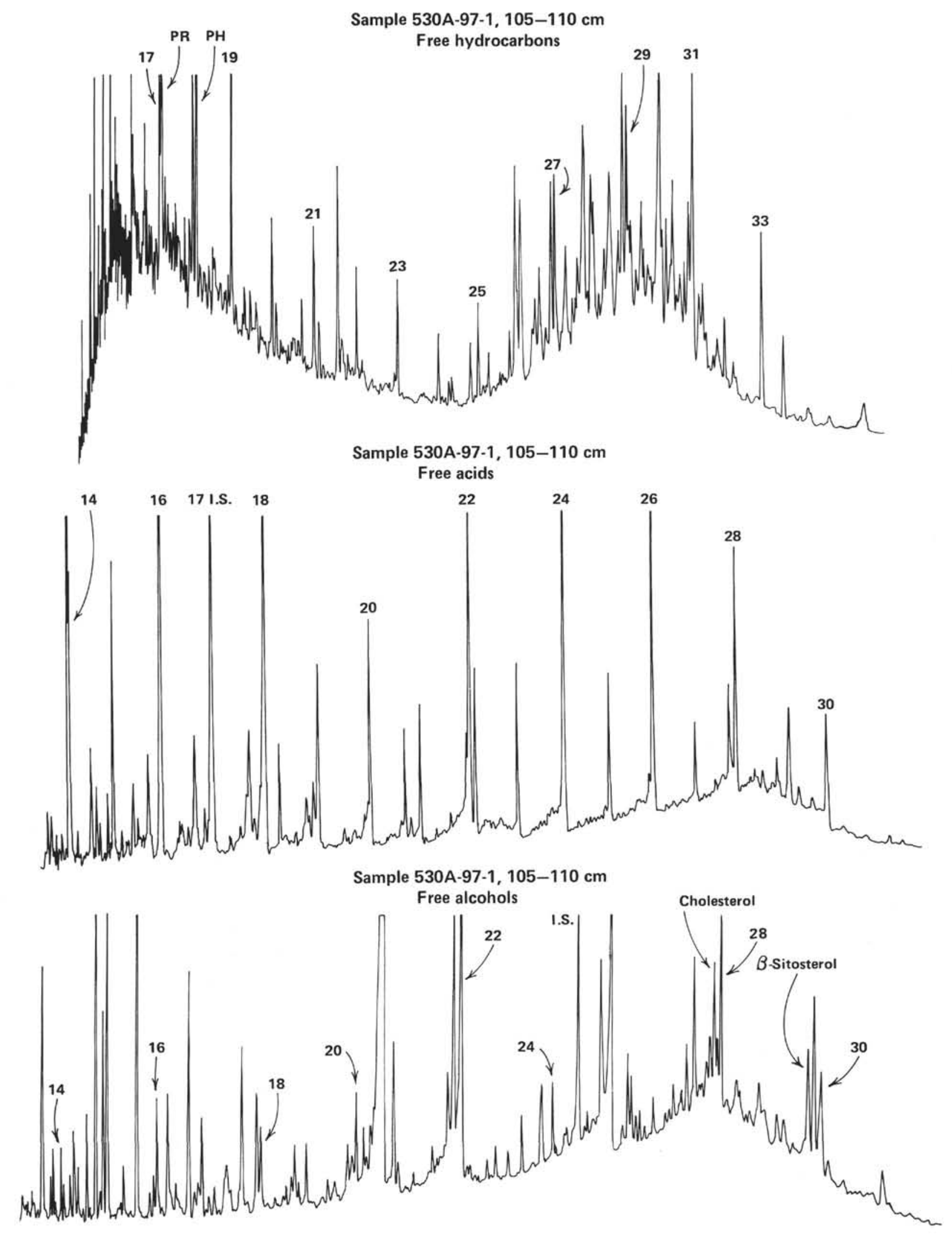

Figure 1. Representative chromatograms of hydrocarbon, fatty acid (as methyl esters), and fatty alcohol plus sterol (as BSTFA ethers) fractions of free and bound extracts. (GC conditions: $20 \mathrm{~m}$ SE54 glass capillary column, hydrogen carrier gas at $2 \mathrm{ml} / \mathrm{min}$., 70 to $270^{\circ} \mathrm{C}$ at $4^{\circ} \mathrm{C} / \mathrm{min}$. Major straight-chain components are identified by carbon numbers.) 

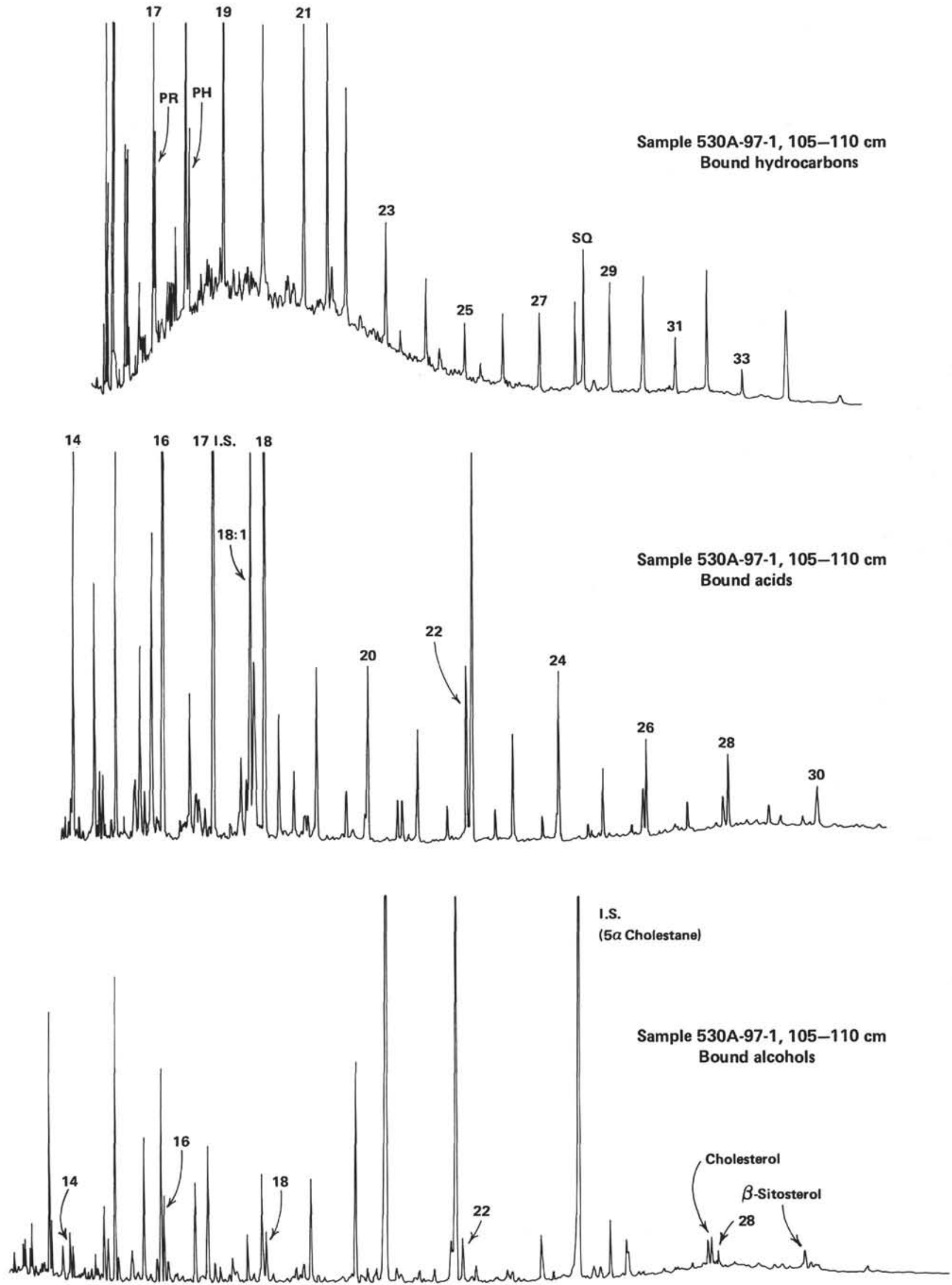

Figure 1. (Continued). 
genated depositional environments during Cenomanian times for both the green claystones and the black shales in Section 530A-97-1. However, this interpretation conflicts with the abundance of sulfur present as pyrite in the black shales (Hay et al., 1982; Site 530 summary, this volume), the presence of porphyrins indicated by strongly colored red bands observed in column chromatography of the extracts from black shales, and the high concentrations of organic carbon in the black shales, all of which suggest anoxic conditions within the sediments (Didyk et al., 1978). The discrepancy between the pristane/phytane ratios and other anoxic/oxic indicators in Section 530A-97-1 may result from thermal enhancement of this ratio similar to that observed by Simoneit et al. (1981) in Cretaceous black shale samples from near a diabase intrusion at DSDP Site 368. However no intrusions are known at DSDP Site 530, and other organic matter parameters remain to be examined to test this possibility.

A high proportion of land-derived organic matter may dilute lipid input from marine algae and result in higher values of the pristane/ $n$-heptadecane ratio in ocean sediments (Didyk et al., 1978). The high values in the free hydrocarbon fractions in rocks from Section 530A-97-1 (Table 2) suggest large contributions of terrigenous organic matter to both green claystones and black shales. Bound hydrocarbon fractions have ratios below one and evidently contain proportionately more algal and microbial organic matter.

Another measure of terrigenous vs. aquatic hydrocarbon origin is the ratio of $\mathrm{C}_{29} / \mathrm{C}_{17} n$-alkanes. Land plants commonly have $n$-alkane distributions dominated by $\mathrm{C}_{27}, \mathrm{C}_{29}$, and $\mathrm{C}_{31}$ hydrocarbons, whereas algae contain mostly shorter-chain $n$-alkanes (Simoneit, 1978b); therefore, high $\mathrm{C}_{29} / \mathrm{C}_{17}$ ratios may indicate large terrigenous contributions of organic matter. In Samples 530A-97-1, $87-91 \mathrm{~cm}$ and $530 \mathrm{~A}-97-1,91-95 \mathrm{~cm}$, this ratio suggests major amounts of land-derived components in the hydrocarbon contents of the green claystone and underlying black shale. Sample 530-97-1, 99-105 cm is from the base of a black shale layer 14-cm thick and may contain about equal portions of terrigenous and aquatic hydrocarbons. The underlying green claystone sample, Sample 530A-97-1, 105-110 cm, has a $\mathrm{C}_{29} / \mathrm{C}_{17}$ ratio which indicates predominance of algal hydrocarbons. However, preferential losses of $n$ - $\mathrm{C}_{17}$ relative to longer-chain $n$-alkanes (cf. Giger et al., 1980) may result in the $\mathrm{C}_{29} /$ $\mathrm{C}_{17}$ ratio presenting an exaggerated indication of the original proportion of land-derived material.

Evidence of alteration of $n$-alkanes can be given by carbon preference indices (CPI) of hydrocarbon extracts from rocks (Bray and Evans, 1961). In general, hydrocarbons in young marine sediments have relatively high CPI values and those in thermally mature rocks have values close to one. Hunt (1979) notes that in situations where essentially no land-derived organic matter is present the CPI value of young sediment can be as low as one, but this is rarely found and does not seem to be the case at Site 530. The CPI's of the green claystones from Section 530A-97-1 are quite low and may reflect considerable hydrocarbon diagenesis in these samples. The black shales from this section have somewhat high- er CPI values, indicating less hydrocarbon maturation or alteration. This difference is consistent with the difference in overall preservation of organic matter in the two types of rocks as evidenced by their organic carbon concentrations.

Distributions of free $n$-alkanes of samples from Section 530A-97-1 are bimodal (Fig. 2), showing both algal $\left(\mathrm{C}_{17}\right.$ to $\left.\mathrm{C}_{19}\right)$ and land plant $\left(\mathrm{C}_{27}\right.$ to $\left.\mathrm{C}_{31}\right)$ inputs. Bound $n$-alkanes do not have strongly bimodal distributions. In the green claystones, the bound distributions have maxima at shorter chain lengths than in the corresponding free fraction. The distribution of bound $n$-alkanes in Sample 530A-97-1, 99-105 cm, a black shale, is skewed towards longer chain-length components, and in general all of the $n$-alkane distributions of the black shale samples seem to contain more land plant materials than do the green claystones.

\section{Fatty Acids}

As indicated by low values of the $\mathrm{C}_{26} / \mathrm{C}_{16} \mathrm{n}$-alkanoic acid ratios (Table 2), the major constituents of fatty acid distributions are shorter-chain $n$-alkanoic acids. The major component in five of the six free acid fractions and in all of the bound fractions is $n-C_{16}$ acid (Fig. 3). Bimodal distributions containing algal $\left(\mathrm{C}_{16}, \mathrm{C}_{18}\right)$ and terrigenous $\left(\mathrm{C}_{24}\right.$ to $\left.\mathrm{C}_{32}\right)$ acids make up the free fractions and resemble the fatty acid distribution of an Aptian black mudstone from DSDP Site 364 in the Angola Basin (Simoneit, 1978a). Bound fractions have smaller contributions of land-plant long-chain acids than do the free fractions. A similar difference between distributions of free and bound acids is reported by Brassell et al. (1980) in Pleistocene-to-Miocene samples from DSDP Site 440 in the Japan Trench. This difference suggests a more autochthonous origin for the bound fractions of lipids in DSDP samples. Peaks having retention times corresponding to those of unsaturated and branched acids were present in most of the fatty acid chromatograms, but identification of these acids awaits further analysis.

Distributions of acids in the green claystones and in the adjacent black shales are not the same. Black shales contain relatively larger proportions of long-chain terrigenous $n$-alkanoic acids. Because postdepositional degradation would preferentially destroy shorter-chain acids (cf. Matsuda and Koyama, 1977), rocks in which organic matter is poorly preserved should retain fewer of these acids than would rocks in which degradation has been retarded. If the original acid contents of the green and black layers had been similar, those of the organic-carbon-lean green claystones should now have relatively small contributions of $\mathrm{C}_{16}$ and $\mathrm{C}_{18}$ components, and this is not the case. On this basis, the difference in distributions probably reflects the input of more landplant acids to the black shales than to the green claystones rather than being a diagenetic result. These terrigenous materials may have been originally deposited on the African continental margin and become transported to their present location by turbidity flow.

CPI values of free acids average $\mathbf{4 . 2}$ for the green claystones and 2.3 for the black shales. In the bound fractions, the respective mean CPI values are 5.9 and 

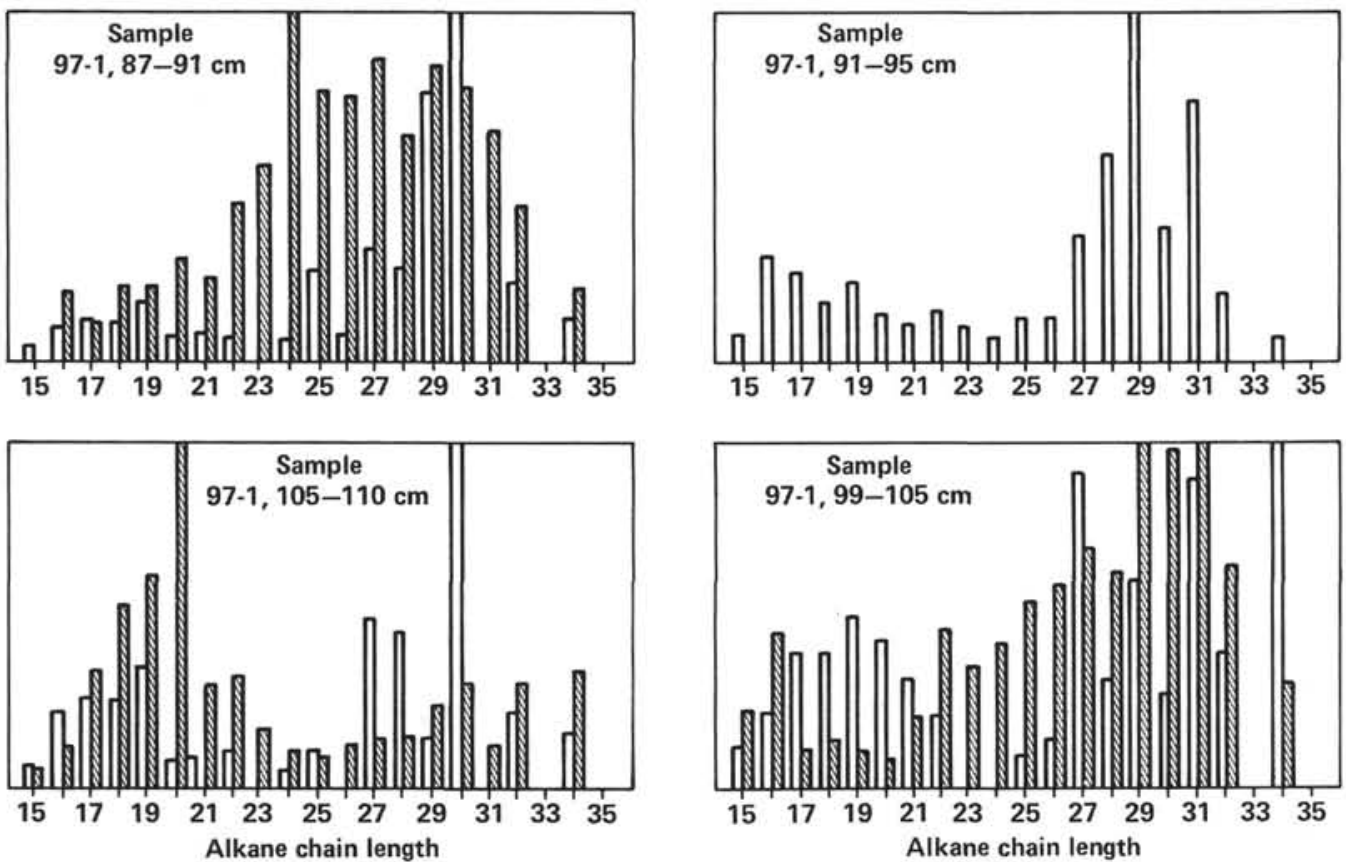

Figure 2. $n$-Alkane distributions in free (open bars) and bound (hachured bars) extracts of hydrocarbons from green claystones (left) and black shales (right).
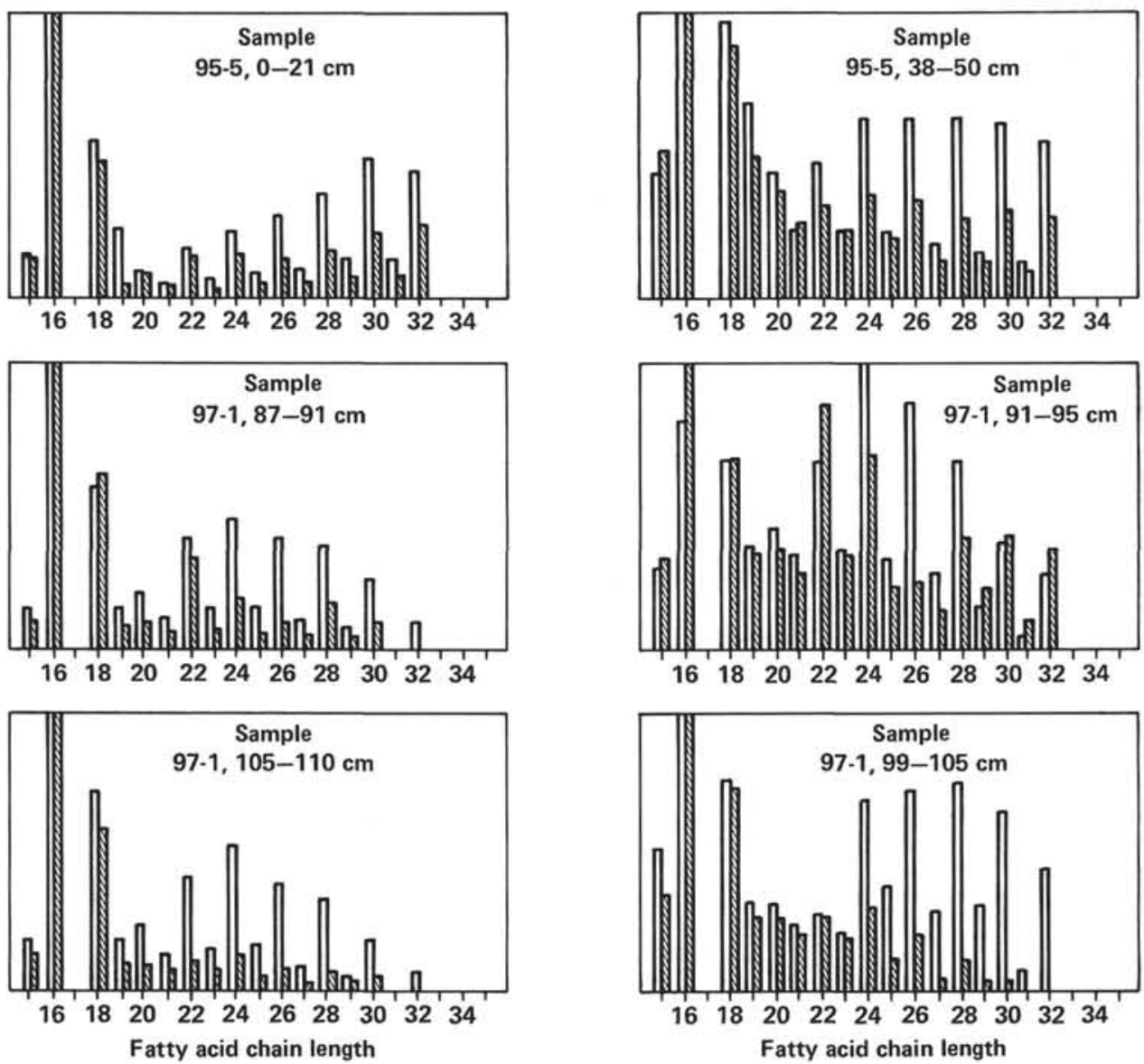

Figure 3. $n$-Alkanoic acid distributions in free (open bars) and bound (hachured bars) extracts of fatty acids from green claystones (left) and black shales (right). 
2.3. Although the higher CPI's of the green claystones reflect the large contributions of $n-\mathrm{C}_{16}$ and $n-\mathrm{C}_{18}$ acids, more odd-chain alkanoic acids appear in the black shale distributions than in those of the green claystones (Fig. $3)$. These odd-chain components are especially evident from $n-\mathrm{C}_{19}$ to $n-\mathrm{C}_{23}$ and may be diagenetically derived from longer-chain acids.

\section{Alkanols}

Most distributions of $n$-alkanols contain large contributions of $C_{16}, C_{22}$, and $C_{28}$ (Fig. 4). The ratio of $n-C_{28}$ to $n-\mathrm{C}_{16}$ is used in Table 2 as an indicator of land plant versus aquatic alkanols. Although this ratio makes no distinction between black shale and green claystone nor between free and bound alkanols, it does show an important contribution of terrigenous material in most of the samples. This conclusion is supported by the abundance of $n-\mathrm{C}_{26}, n-\mathrm{C}_{28}$, and $n-\mathrm{C}_{30}$ in these samples (Fig. 4). The alkanol distributions of the black shales in particular differ from those found in Pleistocene-to-Miocene samples from DSDP Site 362 (Boon et al., 1978) and from DSDP Site 440 (Brassell et al., 1980) in which $n-\mathrm{C}_{22}$ and $n-\mathrm{C}_{24}$ dominate. As also seen in the fatty acid contents, the alkanols indicate more terrigenous material in the black shales than in the green claystones.

Alkanol CPI values in Table 2 are higher than CPI's of alkanes or alkanoic acids from the same samples. Green claystones have higher CPI's than do their adjacent black shales, and free fractions usually have higher CPI's than found for bound alkanols. The lower values of the black shales is similar to the lower alkanoic acid CPI values and may also be the result of diagenetic production of odd-chain components from longer-chain precursors. Because few reports of $n$-alkanol contents of ancient rocks exist, it is difficult to interpret these CPI values. However, the strong predominance of evenchain components in both the black shales and the green claystones seems remarkable. It may be that diagenesis of alkanols does not form shorter-chain homologs but instead decreases the overall amount of alkanols while not greatly modifying the original biogenic character.

\section{Sterols}

Contributions of $\mathrm{C}_{27}, \mathrm{C}_{28}$, and $\mathrm{C}_{29}$ components to the total concentrations of sterols were compared by the scheme of Huang and Meinschein (1979). For this com-
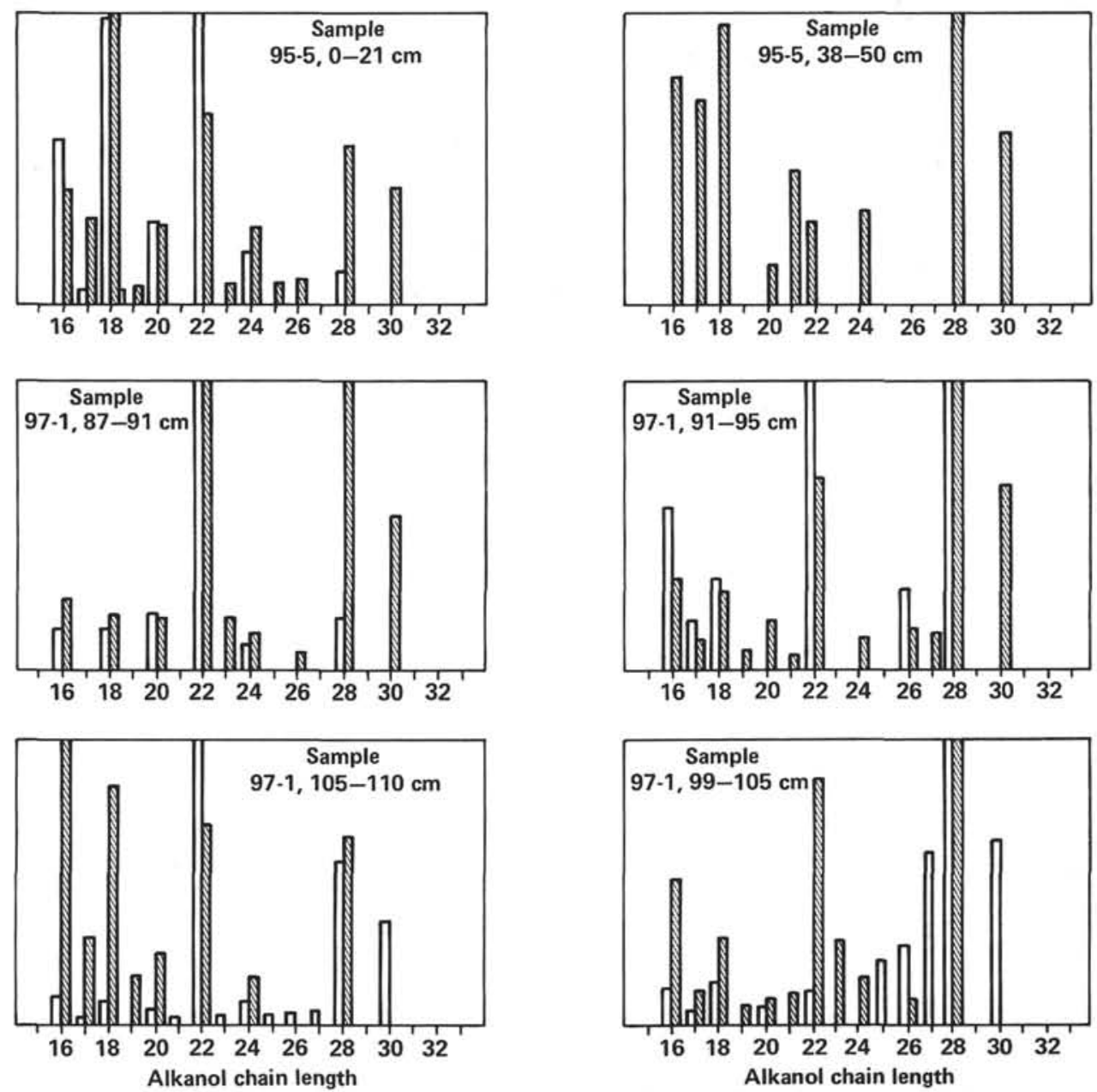

Figure 4. $n$-Alkanol distributions in free (open bars) and bound (hachured bars) extracts of alcohols from green claystones (left) and black shales (right). 
parison, all diene and monoene stenols and stanols having the same carbon number were tentatively identified by $\mathrm{GC}$ retention times and their contributions added together. The comparison (Fig. 5) shows that $\mathrm{C}_{28}$ sterols are not abundant in any of these Cretaceous samples and that $\mathrm{C}_{27}$ and $\mathrm{C}_{28}$ sterols contribute about equally to the totals. Except for the free sterol fractions of two green claystones, most of the samples have similar compositions in both the free and bound fractions. However, these sterol compositions do not resemble those reported by Huang and Meinschein in modern sediments, indicating that the original sterol contents of these sedimentary rocks have been modified. It is possible that sterane distributions, which remain to be determined, will provide better source information, as did those found in the Cretaceous Viking Formation of Canada (Huang and Meinschein, 1979).

Ratios of $\mathrm{C}_{29} / \mathrm{C}_{27}$ stenols range from 0.07 to 2.3 in the free fraction and from 0.08 to 1.1 in the bound. They show no relationship to green or black sample color, nor do the ratios of the free and bound fractions of an individual sample appear to be related. Stenol/stanol ratios are between 1.3 and 35 for $\mathrm{C}_{27}$ sterols and 0.09 and 2.8 for $\mathrm{C}_{29}$ sterols. The large proportion of unsaturated sterols in many of these rocks is surprising in view of the rapid decrease in stenol/stanol ratios usually found in young marine sediments (Huang and Meinschein, 1978). Although it is tempting to conclude that the presence of these unsaturated molecules in the black shales results from exceptional preservation of organic matter, their existence in the organic-carbon-lean green claystones is paradoxical. These preliminary sterol identifications evidently require further investigation.

\section{CONCLUSIONS}

Upper Cretaceous black shales contain higher concentrations of organic carbon and have higher organic matter $\mathrm{C} / \mathrm{N}$ ratios than do adjacent green claystone layers. Lipid contents of both types of rocks consist of similar distributions of marine and terrigenous components, but black shales have somewhat larger proportions of terrigenous $n$-alkanes, $n$-alkanoic acids, and $n$-alkanols than are found in green claystones. The lipid contribution to total organic matter is less in the black shales than in the organic-carbon-lean green claystones, indicating enhanced preservation of nonlipid matter in the black shales and general thermal immaturity of these samples.

The rocks in this study were deposited in the early Angola Basin as turbidites whose source is believed to be on the African continental margin (Hay et al., 1982; Site 530 summary, this volume). The interbedding of thin layers (1 to $15 \mathrm{~cm}$ ) of black shales in thicker layers of green and red claystones and the presence of abundant bioturbation rules out the possibility of permanently anoxic bottom waters during Turonian time. Sediments rich in organic matter may have accumulated where an extended and intensified oxygen minimum zone impinged on the ocean bottom in midwater depths (Demaison and Moore, 1980; Dean et al., 1981). Rede-

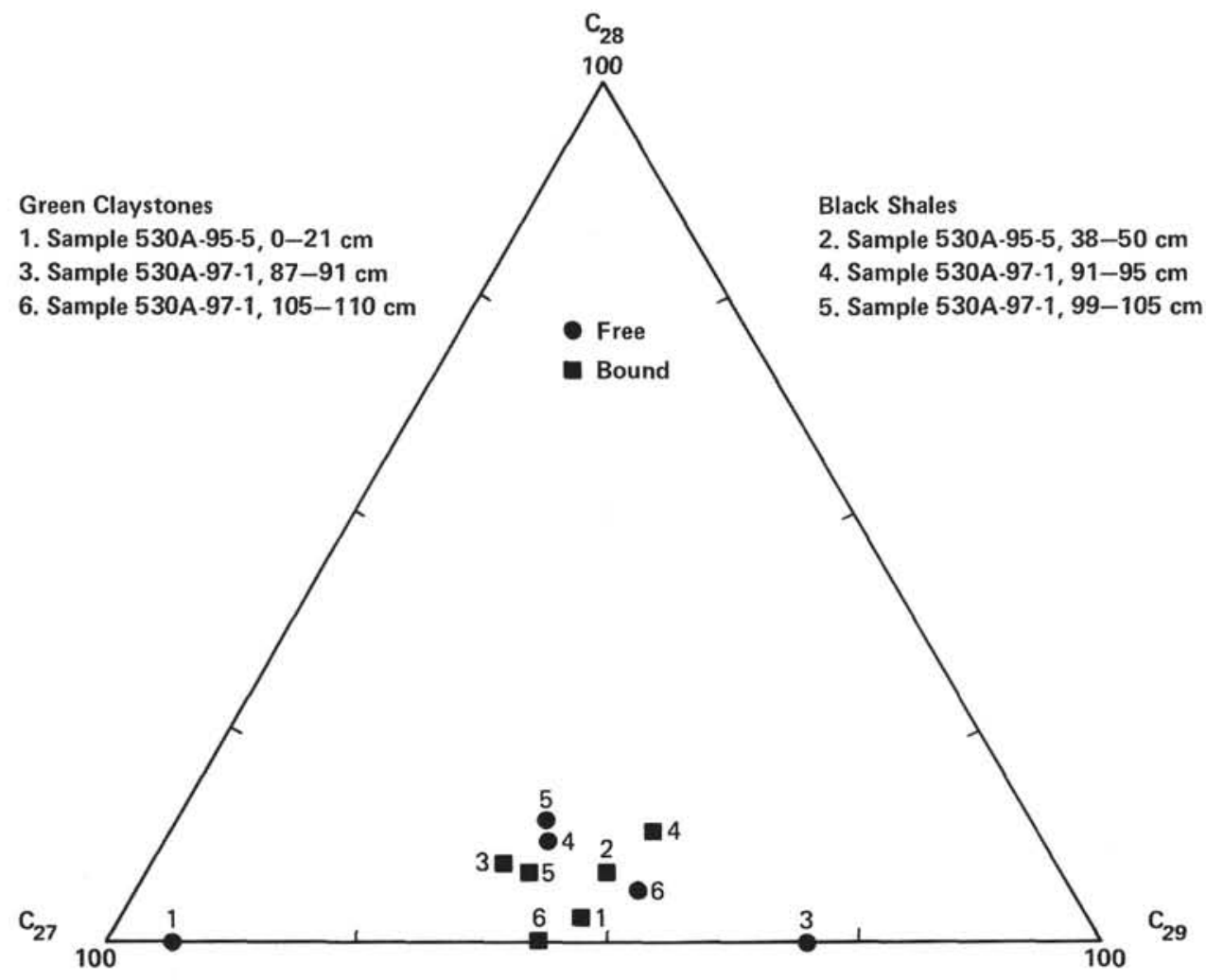

Figure 5. Total $\mathrm{C}_{27}, \mathrm{C}_{28}$, and $\mathrm{C}_{29}$ sterol distributions in free and bound extracts from green claystones and black shales. 
position of these sediments in deeper waters could then have occurred by turbidity flow, and subsequent preservation of organic matter could have been achieved by rapid burial in a nominally oxic environment.

Differences between the green and black layers suggest that variability existed in depositional conditions. If these turbidites came from the same source, then there must have been major fluctuations in the oxygen minimum zone in response to changes in the supply of terrestrial and/or aquatic organic matter. If they had different sources, then the organic-carbon-rich sediments came from a site which received more land-derived material. Organic geochemical data from this investigation suggests that the black shales contain more terrestrial organic matter than do the green claystones. Finally, younger Turonian sediments (Section 530A-95-5) may have been deposited under anoxic conditions on the basis of pristane/phytane ratios, whereas older Turonian sediments (Section 530A-97-1) were laid down under mildly oxic conditions. This difference points out that the conditions leading to black shale formation need not have been the same at all times or at all locations in the oceans.

\section{ACKNOWLEDGMENTS}

We thank W. E. Dean, M. J. Leenheer, J. Rullkötter, and B. R. T. Simoneit for suggesting improvements to the manuscript. We are grateful to the Deep Sea Drilling Project (International Phase of Ocean Drilling) for making possible the participation of P. A. Meyers on board D/V Glomar Challenger during Leg 75.

\section{REFERENCES}

Bolli, H. M., Ryan, W. B. F., and the Shipboard Scientific Party, 1978. Angola continental margin: Sites 364 and 365. In Bolli, H. M., Ryan, W. B. F., et al., Init. Repts. DSDP, 40: Washington (U.S. Govt. Printing Office), 357-455.

Boon, J. J., van der Meer, F. W., Schuyl, P. J. W., de Leeuw, J. W., Schenck, P. A., and Burlingame, A. L., 1978. Organic geochemical analyses of core samples from Site 362, Walvis Ridge, DSDP Leg 40. In Bolli, H. M., Ryan, W. B. F., et al., Init. Repts. DSDP, Suppl. to Vols. $38,39,40$, and 41 : Washington (U.S. Govt. Printing Office), 627-637.

Brassell, S. C., Comet, P. A., Eglinton, G., Isaacson, P. J., McEvoy, J., Maxwell, J. R., Thomson, I. D., Tibbetts, P. J. C., and Volkman, J. K., 1980. Preliminary lipid analyses of Sections 440A-7-6, 440B-3-5, 440B-8-4, 440B-68-2, and 436-11-4: Legs 56 and 57, Deep Sea Drilling Project. In Scientific Party, Init. Repts. DSDP, 56, 57, Pt. 2,: Washington (U.S. Govt. Printing Office), 1367-1390.

Bray, E. E., and Evans, E. D., 1961. Distribution of $n$-paraffins as a clue to recognition of source beds. Geochim. Cosmochim. Acta, 22:2-15.

Cobler, R., and Dymond, J., 1980. Sediment trap experiment on the Galapagos Spreading Center, equatorial Pacific. Science, 209: 801-803.

Dean, W. E., Claypool, G. E., and Thiede, J., 1981. Origin of organic-carbon-rich mid-Cretaceous limestones, mid-Pacific mountains and southern Hess Rise. In Thiede, J., Vallier, T. L., et al., In- it. Repts. DSDP, 62: Washington (U.S. Govt. Printing Office), 877-890.

Degens, E. T., and Mopper, K., 1976. Factors controlling the distribution and early diagenesis of organic material in marine sediments. In Riley, J. P., and Chester, R. (Eds.), Chemical Oceanography (Vol. 6): New York (Academic Press), 59-113.

Demaison, G. J., and Moore, G. T., 1980. Anoxic environments and oil source bed genesis. Org. Geochem., 2:9-31.

Didyk, B. M., Simoneit, B. R. T., Brassell, S. C., and Eglinton, G., 1978. Organic geochemical indicators of palaeoenvironmental conditions of sedimentation. Nature, 272:216-222.

Doran, T., and Johnson, P. G., 1979. Examination of potential geochemical contaminants in Leg 48 material. In Montadert, L., Roberts, D. G., et al., Init. Repts. DSDP, 48: Washington (U.S. Govt. Printing Office), 1157-1160.

Foresman, J. B., 1978. Organic geochemistry DSDP Leg 40, continental rise of southwest Africa. In Bolli, H. M., Ryan, W. B. F. et al., Init. Repts. DSDP, 40: Washington (U.S. Govt. Printing Office), 557-567.

Giger, W., Schaffner, C., and Wakeham, S. G., 1980. Aliphatic and olefinic hydrocarbons in recent sediments of Greifensee, Switzerland. Geochim. Cosmochim. Acta, 44: 119-129.

Hay, W. W., Sibuet, J.-C., and the Shipboard Scientific Party, 1982. Sedimentation and accumulation of organic carbon in the Angola Basin and on Walvis Ridge: Preliminary results of Deep Sea Drilling Project Leg 75. Geol. Soc. Am. Bull., 93:1038-1058.

Hinga, K. R., Sieburth, J. McN., and Heath, G. R., 1979. The supply and use of organic material at the deep-sea floor. J. Mar. Res., 37: 557-579.

Huang, W.-Y., and Meinschein, W. G., 1978. Sterols in sediments of Baffin Bay, Texas. Geochim. Cosmochim. Acta, 42:1391-1396.

1979. Sterols as ecological indicators. Geochim. Cosmochim. Acta, 43:739-745.

Hunt, J. M., 1979. Petroleum Geochemistry and Geology: San Francisco (W. H. Freeman and Company).

McIver, R., 1975. Hydrocarbon occurrences from JOIDES Deep Sea Drilling Project. Proc. Ninth World Pet. Congr., pp. 269-280.

Matsuda, H., and Koyama, T., 1977. Early diagenesis of fatty acids in lacustrine sediments: I. Identification and distribution of fatty acids in recent sediment from a freshwater lake. Geochim. Cosmochim. Acta, 41:777-783.

Muller, P. J., 1977. C/N ratios in Pacific deep-sea sediments: Effect of inorganic ammonium and organic nitrogen compounds sorbed by clays. Geochim. Cosmochim. Acta, 41:765-776.

Simoneit, B. R. T., 1978a. Lipid analyses of sediments from Site 364 in the Angola Basin, DSDP Leg 40. In Bolli, H. M., Ryan, W. B. F. et al., Init. Repts. DSDP, 40: Washington (U.S. Govt. Printing Office), 659-662.

$1978 \mathrm{~b}$. The organic chemistry of marine sediments. In Riley, J. P., and Chester, R. (Eds.), Chemical Oceanography (Vol. 7): London (Academic Press), 233-311.

Simoneit, B. R. T., Brenner, S., Peters, K. E., and Kaplan, I. R., 1981. Thermal alteration of Cretaceous black shale by diabase intrusions in the eastern Atlantic: II. Effects on bitumen and kerogen. Geochim. Cosmochim. Acta, 45:1581-1602.

Stevenson, F. J., and Cheng, C.-N., 1972. Organic geochemistry of the Argentine Basin sediments: Carbon-nitrogen relationships and Quaternary correlations. Geochim. Cosmochim. Acta, 36:653-671.

Waples, D. W., and Sloan, J. R., 1980. Carbon and nitrogen diagenesis in deep sea sediments. Geochim. Cosmochim. Acta, 44: $1463-1470$.

Date of Initial Receipt: June 22, 1982 